\title{
Species of Anastrepha (Diptera: Tephritidae) captured in a guava orchard (Psidium guajava L., Myrtaceae) in Boa Vista, Roraima, Brazil
}

\author{
Marsaro Júnior, AL. ${ }^{a,}{ }^{*}$, Deus, EG. ${ }^{b}$, Ronchi-Teles, $B{ }^{c}$, Adaime, R. $^{d}$ and Silva Júnior, RJ. ${ }^{e}$ \\ ${ }^{a}$ Embrapa Trigo, Rodovia BR 285, km 294, Caixa postal 451, CEP 99001-970, Passo Fundo, Rio Grande do Sul, Brazil \\ ${ }^{b}$ Fellow in CNPq human resource stability program. Embrapa Amapá, Rodovia JK, km 5, No. 2600, CEP 68903-419, \\ Macapá, Amapá, Brazil \\ 'Instituto Nacional de Pesquisas da Amazônia, Av. André Araújo, No. 2936, Petrópolis, CEP 69067-375, Manaus, \\ Amazonas, Brazil \\ ${ }^{d}$ Embrapa Amapá, Rodovia JK, km 5, No. 2600, CEP 68903-419, Macapá, Amapá, Brazil \\ ${ }^{e}$ Embrapa Roraima, Rodovia BR 174, km 8, CEP 69301-970, Boa Vista, Roraima, Brazil \\ *e-mail: alberto.marsaro@embrapa.br
}

Received August 27, 2012 - Accepted October 26, 2012 - Distributed November 29, 2013

(With 2 figures)

\begin{abstract}
The guava fruit (Psidium guajava) is among the most strongly affected by fruit flies in Brazil. In the Brazilian Amazon, 11 species of Anastrepha have been reported in guava orchards to date. This work aimed to identify the species of Anastrepha present in a guava orchard in the municipality of Boa Vista, determine the species infesting the fruits, and identify any parasitoids present. Two McPhail traps with food bait were installed and weekly collections were made between January and December 2008. Fruits were also collected systematically during this period, with a view to determining the association between host plant and tephritid species. Nine species of Anastrepha were identified, in addition to one specimen belonging to a probable new species. Anastrepha striata Schiner, Anastrepha sororcula Zucchi, Anastrepha obliqua (Macquart), and Anastrepha fraterculus (Wiedemann) were the dominant species in the orchard, accounting for $84.8 \%$ of all captured individuals. All females collected directly from fruits were A. striata. Doryctobracon areolatus (Szépligeti) was the only parasitoid species obtained. In this work, Anastrepha ethalea (Walker) is reported for the first time in the state of Roraima.
\end{abstract}

Keywords: Amazon, Anastrepha ethalea, Anastrepha striata, fruit flies.

\section{Espécies de Anastrepha (Diptera: Tephritidae) capturadas em pomar de goiabeira (Psidium guajava L., Myrtaceae) em Boa Vista, Roraima, Brasil}

\section{Resumo}

A goiaba (Psidium guajava) é uma das frutas mais afetadas pelas moscas-das-frutas no Brasil. Na Amazônia brasileira 11 espécies de Anastrepha já foram relatadas nesta cultura. O presente trabalho teve como objetivos identificar as espécies de Anastrepha presentes em um pomar de goiabeira no município de Boa Vista, verificar quais espécies infestam os frutos e identificar os parasitoides presentes. Foram instaladas duas armadilhas tipo McPhail, contendo atrativo alimentar, sendo as coletas realizadas semanalmente, de janeiro a dezembro de 2008. Para determinar a associação entre a planta hospedeira e as espécies de tefritídeos foram realizadas coletas sistemáticas de frutos no mesmo período. Nove espécies de Anastrepha foram identificadas, além dessas foi obtido um exemplar pertencente a uma provável espécie nova. Anastrepha striata Schiner, Anastrepha sororcula Zucchi, Anastrepha obliqua (Macquart) e Anastrepha fraterculus (Wiedemann) foram as espécies dominantes no pomar e representaram 84,8\% dos indivíduos capturados. Todas as fêmeas coletadas diretamente dos frutos pertenciam à espécie $A$. striata. Doryctobracon areolatus (Szépligeti) foi a única espécie de parasitoide obtida. Neste trabalho, Anastrepha ethalea (Walker) é assinalada pela primeira vez no estado de Roraima.

Palavras-chave: Amazônia, Anastrepha ethalea, Anastrepha striata, moscas-das-frutas. 


\section{Introduction}

The guava Psidium guajava L. (Myrtaceae) is a native species of tropical America, possibly ranging from Mexico to Peru, where it still occurs in a naturally occurring state (Menzel, 1985). The species is widely distributed and can be found in all tropical and subtropical regions (Gould and Raga, 2002).

Brazil is one of the world's largest producers of guava, with most of this production originating from commercial orchards and small agricultural properties where guava is cultivated in household orchards (Gould and Raga, 2002). Production volume in 2009 was 328,255 tonnes in a 15,012 hectare area, concentrated mainly in the southeast and northeast regions of the country (Agrianual, 2009; Ramos et al., 2010). The state of São Paulo is the largest producer, with 5,076 hectares planted, followed by the state of Pernambuco, with 4,512 hectares (Agrianual, 2009).

Despite these expressive production levels, the presence of pest insects compromises the health of Brazilian guava crops and is a major obstruction to guava commercialisation, both in the domestic and international markets. In this context, fruit flies (Diptera: Tephritidae) are considered extremely important because they are the most common fruit pests, causing not only direct damage to the product, but also commercial limitations (Malavasi, 2000).

Among Tephritidae, the genus Anastrepha Schiner is considered the most diverse and the most economically relevant in the Americas. The genus is endemic to the New World and restricted to tropical and subtropical environments. It is comprised of approximately 235 species, divided into 18 groups (Aluja, 1994; Uramoto et al., 2008; Uchôa and Nicácio, 2010). Out of this total, 115 species have already been reported in Brazil. Host plants have been identified for only 56 of those species. Anastrepha fraterculus (Wiedemann, 1830) and Anastrepha obliqua (Macquart, 1835) are the most polyphagous species, with 97 and 45 host plants respectively (Zucchi, 2008). A total of 56 species of Anastrepha have been reported in the Brazilian Amazon, of which 32 are exclusive to the region (Norrbom and Uchôa 2011; Zucchi et al., 2011).

Fruit flies are considered key pests of guava, including some species of quarantine importance (Gould and Raga, 2002). In the Americas, Anastrepha striata Schiner, 1868 is strongly associated with guava (Jirón and Hedström, 1988; Katiyar et al., 2000; Caraballo, 2001; Zucchi, 2008; Birke and Aluja, 2011). In Brazil, 11 species of Anastrepha have already been reported on guava crops, in addition to the exotic species Bactrocera carambolae Drew \& Hancock, 1994 and Ceratitis capitata (Wiedemann, 1824) (Zucchi, 2001, 2008; Silva et al., 2011a, b).

In the state of Roraima, located in the extreme north of Brazil, the first studies and data on Anastrepha species began to be published in the 1990 s, beginning with Rafael (1991). Later, a number of reports added new infor- mation on Anastrepha species richness in the state (Marsaro Júnior et al., 2011a). To date, 24 species of Anastrepha have been reported in Roraima (Marsaro Júnior et al., 2011a, b; Adaime et al., 2012; Marsaro Júnior et al., 2012; Marsaro Júnior et al., 2013).

The objectives of this work were: to perform a faunistic analysis based on the Anastrepha species captured in McPhail traps in a guava orchard in Boa Vista, Roraima; identify the species infesting the collected guava fruits; and identify their associated parasitoids.

\section{Material and Methods}

\subsection{Study site}

The municipality of Boa Vista is located in the northeast of the state of Roraima, Brazil. The state presents three climate groups under the Köppen classification system: Aw, Af, and Am. The Aw climate region corresponds to the savannas in center-eastern and northeastern Roraima. This type of climate is characterised by a marked, well-defined dry period, in this case between the months of December and March. Average annual rainfall in this region is $1,655 \pm 408 \mathrm{~mm}$. From that total, approximately $9 \%$ falls at the peak of the dry season (December-March) and $70 \%$ at the peak of the rainy season (May-August) (Barbosa, 1997; Araújo et al., 2001). The Af climate type is observed in the forest systems of the extreme south and northwest of Roraima. These regions are predominantly covered by dense ombrophilous forests, with annual rainfall averages of more than $2,000 \mathrm{~mm}$. Am-type climate is found in the contact forests and grassland regions, where average annual rainfall ranges from 1,700 to $2,000 \mathrm{~mm}$.

The studies were conducted in a guava orchard $\left(02^{\circ} 53^{\prime} \mathrm{N}-60^{\circ} 39^{\prime} \mathrm{W}\right.$, altitude 85 meters) located in the municipality of Boa Vista, Roraima, Brazil. The orchard had the following characteristics: 1.3 hectare containing 538 trees of the 'Paluma' cultivar, each approximately 5 years old, planted at intervals of 4 metres between trees and 6 metres between rows.

Three prunings were performed during the collection period (January through December 2008): one wholeorchard pruning in January; a half-orchard pruning in July; and the other half in September. The trees yielded fruit year-round because the orchard is irrigated. However, fruit availability varied throughout the year, with greatest abundance in April, May, September, October, and December. Other fruit trees were also cultivated in the vicinity of the guava orchard, including mango (Mangifera indica L.), soursop (Annona muricata L.), passion fruit (Passiflora edulis Sims), and other fruit trees dispersed in the nearby domestic orchards, such as jaboticaba [Myrciaria cauliflora (Mart.) O. Berg.], acerola (Malpighia emarginata Sessé \& Moc. ex DC.), star fruit (Averrhoa carambola L.), and Brazilian guava (Psidium guineense Swartz). There was also an area with native vegetation characteristic of the cerrado (savanna) biome. 


\subsection{Sampling with traps}

Two McPhail traps were installed, each baited with $400 \mathrm{~mL}$ of food bait containing $5 \%$ hydrolyzed corn protein (BioAnastrepha $\left.{ }^{\circledR}\right)$ stabilized with borax. Collections were conducted weekly, from January through December 2008, yielding a total of 53 samples. At each inspection, the contents of the traps were poured onto a sieve and subsequently stored in plastic containers. The traps were then washed and the food bait replaced. The traps were subsequently reattached to the trees.

The captured insects were stored in labeled containers of $70 \%$ ethanol and transported to the Entomology Laboratory at Embrapa Roraima in Boa Vista, where they underwent preliminary identification.

\subsection{Fruit sampling}

Guava fruits were systematically collected during the sampling period, aiming to confirm the association between the host plant and the tephritid species occurring in the area. At each sampling occasion, 10 ripe fruits were collected at random, directly from the trees. The fruits were packed in coolboxes and transported to the Entomology Laboratory at Embrapa Roraima. In the laboratory, the fruit samples were processed as per Silva et al. (2007a). The fruits were counted, weighed and arranged on plastic trays over a thin layer of vermiculite, which served as a pupation substrate. The trays were covered with organza fabric fastened in place with rubber straps. Every three days, the vermiculite was examined and the puparia were removed using spatulas. The puparia were transferred into transparent plastic flasks ( $8 \mathrm{~cm}$ diameter) with vented lids covered with organza, containing a thin layer of moistened vermiculite. The samples were discarded after twenty days.

The flasks containing the puparia were kept in climate-controlled chambers under controlled temperature $\left(26.5 \pm 0.5^{\circ} \mathrm{C}\right)$, relative humidity $(70 \pm 5 \%)$ and photophase (12 hours). They were observed and moistened daily. After the adult insects emerged, they were stored in labeled flasks of $70 \%$ ethanol for subsequent identification.

\subsection{Data analysis}

The following faunistic indexes were used in the quantitative analysis: frequency, dominance and constancy.

\subsubsection{Frequency}

Frequency is the number of individuals of a given species in relation to the total number of individuals in the sample; $p_{i}=n_{i} / \mathrm{N}$, where $n_{i}$ is the number of individuals of species $i$, and $N$ is the total number of individuals in the sample (Silveira-Neto et al., 1976).

\subsubsection{Dominance}

Dominance was determined by calculating the limit of dominance as $\mathrm{LD}=(1 / \mathrm{S}) \times 100$, as proposed by Sakagami and Laroca (1971), where LD is the limit of dominance and $\mathrm{S}$ is the total number of species. A species is considered dominant when its frequency is higher than $(1 / \mathrm{S}) \times 100$

\subsubsection{Constancy}

Constancy is the percentage of samples in which a given species was present. $\mathrm{C} \%=p .100 / \mathrm{N}$, where $p$ is the number of samples containing the species and $\mathrm{N}$ is the total number of samples (Dajoz, 1983). According to their constancy percentages, the species were grouped into the following categories:

- Constant species (w): present in more than $50 \%$ of samples

- Accessory species (y): present in $25-50 \%$ of samples

- Accidental species (z): present in less than $25 \%$ of samples

The infestation indexes of the fruits were calculated in 2 ways: (1) by dividing the total number of puparia obtained by the number of fruits in the sample (puparia/fruit); and (2) by dividing the total number of puparia by the total mass ( $\mathrm{kg}$ ) of fruits in the sample (puparia $/ \mathrm{kg}$ ).

\subsection{Identification of specimens}

The obtained specimens (fruit flies and parasitoids) were identified to species level at the INPA Entomology Laboratory (Manaus, Brazil) and Embrapa Amapá (Macapá, Brazil), based on identification keys by Zucchi (2000) and Canal and Zucchi (2000). Voucher specimens were deposited in the collections of these laboratories.

\section{Results}

\subsection{Species richness}

A total of 423 specimens of Anastrepha (296 females and 127 males) were captured during the sampling period. Nine species were identified: Anastrepha bahiensis Lima, 1937; Anastrepha distincta Greene, 1934; Anastrepha ethalea Walker, 1849; Anastrepha fraterculus (Wiedemann, 1830), Anastrepha obliqua (Macquart, 1835); Anastrepha sororcula Zucchi, 1942; Anastrepha striata Schiner, 1868; Anastrepha turpiniae Stone, 1942; and Anastrepha zenildae Zucchi, 1979. In addition to these species, one of the captured specimens of Anastrepha probably belongs to a new species.

Anastrepha striata, A. sororcula, A. obliqua, and $A$. fraterculus were the most frequent and dominant species in the orchard, accounting for $84.8 \%$ of the captured specimens. However, only A. striata was considered constant. The other captured species were observed at low frequencies (Table 1).

The number of captured specimens varied throughout the year. Figure 1 presents the fluctuation of dominant species in the guava orchard. Anastrepha striata, $A$. sororcula and $A$. fraterculus presented population peaks in June, whereas the A. obliqua population peaked in March. On both months, guava fruit availability in the orchard was low. 
Table 1 - Frequency, dominance and constancy of Anastrepha species captured in McPhail traps in a guava orchard in Boa Vista, state of Roraima, Brazil, January through December 2008 (number of samples $=53$ ).

\begin{tabular}{lcccc}
\hline Species of Anastrepha & N & Frequency (\%) & Dominance & Constancy \\
\hline Anastrepha striata* $^{*}$ & 122 & 41.22 & $\mathrm{~d}$ & $98.11(\mathrm{w})$ \\
Anastrepha sororcula** $^{*}$ & 56 & 18.92 & $\mathrm{~d}$ & $20.75(\mathrm{z})$ \\
Anastrepha obliqua** $^{*}$ & 42 & 14.19 & $\mathrm{~d}$ & $13.2(\mathrm{z})$ \\
Anastrepha fraterculus** $^{*}$ & 31 & 10.47 & $\mathrm{~d}$ & $20.75(\mathrm{z})$ \\
Anastrepha zenildae** & 29 & 9.80 & $\mathrm{n}$ & $15.09(\mathrm{z})$ \\
Anastrepha turpiniae** & 9 & 3.04 & $\mathrm{n}$ & $16.98(\mathrm{z})$ \\
Anastrepha ethalea*** & 3 & 1.01 & $\mathrm{n}$ & $5.66(\mathrm{z})$ \\
Anastrepha bahiensis** & 2 & 0.67 & $\mathrm{n}$ & $1.88(\mathrm{z})$ \\
Anastrepha distincta** & 1 & 0.34 & $\mathrm{n}$ & $1.88(\mathrm{z})$ \\
Anastrepha sp. & 1 & 0.34 & $\mathrm{n}$ & $1.88(\mathrm{z})$ \\
Total & 296 & 100.00 & - & - \\
\hline
\end{tabular}

* serpentina group, ** fraterculus group, ${ }^{* * *}$ pseudoparallela group, $\mathrm{N}$ : total number of females collected, $\mathrm{d}$ : dominant, $\mathrm{n}$ : non-dominant, w: constant, z: accidental.

\subsection{Infestation of fruits}

Guava fruits were sampled 27 times, comprising a total weight of 41 kilograms. From the total of 719 puparia obtained from these samples, 417 specimens of Anastrepha emerged (217 females and 200 males), as well as two specimens of Braconidae (Hymenoptera). All of the females belonged to the species $A$. striata, which was present in all of the collected samples. Parasitoids were obtained from only two samples, indicating a low frequency of such insects in the orchard. Doryctobracon areolatus (Szépligeti, 1911) was the only parasitoid species identified. The observed rates of parasitism were $8.3 \%$ and $2.5 \%$ on February 1 and July 15, 2008, respectively.

The average rates of infestation ranged from 0.50 to 11.30 puparia/fruit and 2.63 to 85.77 puparia/ $\mathrm{kg}$ of fruit. The highest rates of infestation were recorded in the period between June 18 and October 7, 2008 (Figure 2), coinciding with the population peak of three among the four dominant species (Figure 1).

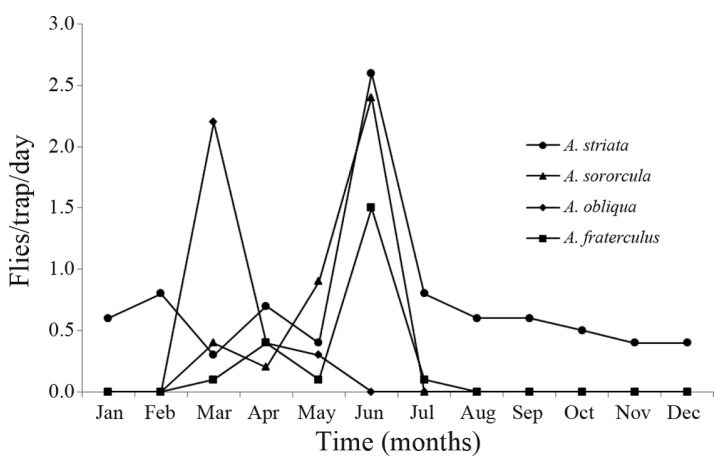

Figure 1 - Number of adults of dominant Anastrepha species per trap in a guava orchard, Boa Vista, state of Roraima, Brazil, January through December 2008.

\section{Discussion}

\subsection{Species richness}

The most frequent and dominant species in this work, i.e., Anastrepha striata, A. sororcula, A. obliqua, and A. fraterculus, have been reported as the most important guava pests in Brazil. Anastrepha striata is only considered a key pest of this crop in the North region of the country (Zucchi et al., 2011). In the Northeast, CenterWest, Southeast, and South regions of Brazil, $A$. fraterculus, A. obliqua, A. sororcula, A. zenildae, and the exotic species Ceratitis capitata are the most relevant species, alternating in dominance according to location (Uchôa et al., 2002; Raga et al., 2005; Moura and Moura, 2006; Dutra et al., 2009; Azevedo et al., 2010).

The dominance of Anastrepha striata has also been observed in other works conducted in northern Brazil.



Figure 2 - Rates of guava fruit infestation by Anastrepha striata in a guava orchard, Boa Vista, state of Roraima, Brazil, January through December 2008. 
Deus et al. (2009a) reported $A$. striata as the most important species in a guava orchard in the state of Amapá. The authors observed that approximately $81 \%$ of all captured specimens were A. striata. Ronchi-Teles and Silva (2005) observed that $A$. striata was dominant during the guava fruiting period, in a study conducted in the state of Amazonas.

According to Aluja (1994) and Celedônio-Hurtado et al. (1995), the level of species dominance appears to be determined by a group of ecological components, the most important of which are the richness, diversity, and abundance of hosts. The dominance of $A$. striata can therefore be explained by the abundance of guava fruits, its main host in the Amazon region.

Anastrepha obliqua is the second most economically important tephritid species in the north region of Brazil. Anacardiaceae plant species are its preferred hosts; this means that the high frequency of $A$. obliqua in the region is contingent on the presence of its primary hosts. Thomazini et al. (2003) and Bomfim et al. (2007) reported a high frequency of $A$. obliqua in commercial orchards in the states of Acre and Tocantins, respectively. The authors attributed this fact to the presence of Anacardiaceae fruit trees including mango (Mangifera indica L.), jocote (Spondias purpurea L.), and cashew (Anacardium occidentale L.), which are all reported hosts of A. obliqua in the region (Zucchi et al., 2011). A. obliqua presented the third highest frequency in this study; however, during the sampling period, no specimens of this species were obtained from guava fruits, suggesting that its host plants may be present in the vicinity of the orchard.

Despite being classified as dominant in this work, Anastrepha sororcula and A. fraterculus are found at a low frequency in northern Brazil. Anastrepha sororcula, A. zenildae and Ceratitis capitata have been frequently reported as guava pests in the northeast, southeast and south regions of Brazil, where A. striata is reported as low frequency or absent (Moura and Moura, 2006; Souza-Filho et al., 2009; Dutra et al., 2009). In the Brazilian Amazon, A. sororcula has been reported in the states of Amapá, Maranhão, Mato Grosso, Pará, Roraima, and Tocantins (Zucchi et al., 2011).

Anastrepha fraterculus is the most widely distributed tephritid in Brazil, but its importance to agriculture is significantly less in the northern regions of the country than in the south. In south and southeast Brazil, up to the centre-south of the state of Minas Gerais, A. fraterculus is considered an important primary pest of fruit crops (Malavasi et al., 2000); however, in the north region of Brazil, this tephritid is considered a secondary species with marginal distribution (Malavasi et al., 2000; Silva and Ronchi-Teles, 2000). In the Brazilian Amazon, $A$. fraterculus has been reported in the states of Amapá, Maranhão, Pará and Tocantins, in association with 10 plant species (Zucchi et al., 2011).

In this work, Anastrepha ethalea is reported for the first time in the state of Roraima. In Brazil, this species occurs in the states of Pará, Maranhão and Piauí, and no host plants have been identified to date (Zucchi, 2008).
The occurrence pattern of Anastrepha striata in the area studied in this work indicates that this species is the best adapted to the local conditions, given its constant occurrence in the orchard and the fact that it was the only species obtained from the sampled fruits. Duyck et al. (2004) emphasized that the dominance of Tephritidae species depends on temperature, latitude and longitude, humidity, host plant quality and other factors that can influence larval development time. Although the influence of these factors was not assessed in this work, some previous studies conducted in the Brazilian Amazon have already indicated that $A$. striata is the dominant species in guava crops (Silva et al., 2007a, b; Deus et al., 2009b; Pereira et al., 2010).

The population peaks observed for Anastrepha striata, A. fraterculus, and $A$. sororcula showed that the abundance of these species increased between May and July and diminished considerably in the subsequent months; however, in the case of $A$. striata, the population decline was not as drastic and specimens were collected year-round, at rates nearing $0.5 \mathrm{fly} /$ trap/day (Figure 1). This result may be explained by the availability of guava fruits to A. striata throughout the entire period of collection in the orchard. In the studies conducted by Araujo and Zucchi (2003), Moura and Moura (2006), Araujo et al. (2008), Dutra et al. (2009) and Santos et al. (2011), the abundance of dominant fruit fly species was attributed to the presence of host plant species. In this study, only the results obtained for $A$. striata confirm the results of the foregoing authors. The abundance of the other dominant species found in this study -i.e., A. sororcula, A. obliqua and $A$. fraterculus, - may be related to the presence of preferred or alternative host fruits in the vicinity of the orchard, given that during the periods when preferred hosts are unavailable, alternative hosts assume an important role in the maintenance of fruit fly populations (Aguiar-Menezes and Menezes, 1996).

Interspecific competition is another factor that may explain the infestation of guava fruits exclusively by Anastrepha striata despite the presence of other species in the orchard. Duyck et al. (2006) emphasized that females that are ready to oviposit may compete directly; another possibility is that the very act of ovipositing may make infestation by another tephritid more difficult, as the fruits are marked with a pheromone. Therefore, the dominance of $A$. striata in the studied orchard seems to be favoured by a number of different factors (biotic and abiotic), although these factors were not assessed in this work.

The other species of Anastrepha were represented by few individuals, which may have been present because they were searching for food.

\subsection{Infestation of fruits}

Studies conducted in the Brazilian Amazon have indicated that Anastrepha striata is the pest species that causes the greatest damage to guava crops. The tephritid has been associated with guava in eight of the nine states that comprise the Brazilian Amazon (Silva et al., 2011c). 
In previous works in the state of Amapá, Silva et al. $(2007 \mathrm{a}, \mathrm{b})$ observed that $A$. striata was the only species present in guava fruits. A similar result was also obtained in Amapá by Deus et al. (2009b) and in the states of Acre and Rondônia by Pereira et al. (2010), who reported that A. striata was predominant in guava, although other species were also present.

In other Latin American countries, Anastrepha striata has also been reported as one of the main pests of guava. In Costa Rica, A. striata was detected in $97.8 \%$ of all sampled guava fruits (Jirón and Hedström, 1988, Jirón et al., 1988). In Ecuador, A. striata emerged from 70.8\% of the examined fruits (Hedström, 1987). In Venezuela, when assessing infestation in species of the genus Psidium L., Katiyar et al. (2000) reported that $A$. striata is the dominant species in Psidium guajava. In Mexico, Birke and Aluja (2011) observed that $A$. striata is dominant in guava fruits in low altitude areas.

The rates of parasitism observed in Anastrepha striata in guava fruits, i.e., $8.3 \%$ on February 1 and $2.5 \%$ on July 15, 2008, are similar to the rates already reported for this species in Psidium guajava in the state of Roraima by Marsaro Júnior et al. (2011b). The only parasitoid species identified in this work, Doryctobracon areolatus - which has already been associated with several species of Anastrepha in several host plants in the state of Roraima (Marsaro Júnior et al., 2011a) -, is the most widely distributed parasitoid in Brazil (Leonel Júnior et al., 1995; Canal and Zucchi, 2000) and Latin America (Ovruski et al., 2000).

The high rates of infestation by Anastrepha striata reported in this study reinforce the results of other works conducted in the Brazilian Amazon that reported this species as a key pest of guava crops. However, new studies are required for a better understanding of the relationship between tephritid species present in the orchard and between those species and Psidium guajava, given that little information is available on several aspects of the ecology and behavior of Tephritidae in the North region of Brazil. Studies aiming to identify the influence of biotic and abiotic factors on the population dynamics of fruit flies in the Brazilian Amazon should therefore be encouraged, especially long-term studies involving the fruit pest species found in the region.

\section{Conclusions}

Anastrepha striata, A. sororcula, A. obliqua and $A$. fraterculus are the most frequent and dominant species in the guava orchard. Anastrepha striata was the only species obtained from the guava fruits. Doryctobracon areolatus, a parasitoid associated with $A$. striata, was the only parasitoid observed in this study.

\section{Acknowledgments}

To CNPq for the fellowships granted to Ricardo Adaime (Research Productivity Fellowships) and Ezequiel G. Deus (Human Resource Stability Fellowship).

\section{References}

ADAIME, R., MARSARO JÚNIOR, AL., SOUZA-FILHO, MF., CHAGAS, EA. and LIMA, CGB., 2012. New host of Anastrepha parishi Stone (Diptera: Tephritidae) reported in Brazil. Brazilian Journal of Biology, vol. 72, no. 1, p. 227.

AGRIANUAL, 2009. Anuário estatístico da Agricultura Brasileira. São Paulo: FNP Consultoria \& Comércio. 495 p.

AGUIAR-MENEZES, EL. and MENEZES, EB., 1996. Flutuação populacional das moscas-das-frutas e sua relação com a disponibilidade hospedeira em Itaguaí, RJ. Anais da Sociedade Entomológica do Brasil, vol. 25, no. 2, p. 223-232.

ALUJA, M., 1994. Bionomics and management of Anastrepha. Annual Review of Entomology, vol. 39, p. 155-178.

ARAUJO, EL. and ZUCCHI, RA., 2003. Moscas-das-frutas (Diptera: Tephritidae) em goiaba (Pisidium guajava), em Mossoró, RN. Arquivos do Instituto Biológico, vol. 7, no. 1, p. 73-77.

ARAÚJO, WF., ANDRADE-JÚNIOR., AS., MEDEIROS, RD. and SAMPAIO, RA., 2001. Precipitação pluviométrica mensal provável em Boa Vista, Estado de Roraima, Brasil. Revista Brasileira de Engenharia Agrícola e Ambiental, vol. 5, no. 3, p. 563-567.

ARAUJO, EL., SILVA, RKB., GUIMARÃES, JA., SILVA, JG. and BITTENCOURT, MAL., 2008. Levantamento e flutuação populacional de moscas-das-frutas (Diptera: Tephritidae) em goiaba Psidium guajava L., no município de Russas (CE). Revista Caatinga, vol. 21, no. 1, p. 138146.

AZEVEDO, FR., GUIMARÃES, JA., SIMPLÍCIO, AAF. and SANTOS, HR., 2010. Análise faunística e flutuação populacional de moscas-das-frutas (Diptera: Tephritidae) em pomares comerciais de goiaba na região do cariri cearense. Arquivos do Instituto Biológico, vol. 77, no. 1, p. 33-41.

BARBOSA, RI., 1997. Distribuição das chuvas em Roraima. In BARBOSA, RI., FERREIRA, EJG. and CASTELLÓN, EG. (Eds.). Homem, ambiente e ecologia no estado de Roraima. Manaus: INPA. p. 325-335.

BIRKE, A. and ALUJA, M., 2011. Anastrepha ludens and Anastrepha serpentina (Diptera: Tephritidae) do not infest Psidium guajava (Myrtaceae), but Anastrepha obliqua occasionally shares this resource with Anastrepha striata in nature. Journal of Economic Entomology, vol. 104, no. 4, p. 1204-1211.

BOMFIM, DA., UCHÔA, MA. and BRAGANÇA, MAL., 2007. Biodiversidade de moscas-das-frutas (Diptera, Tephritoidea) em matas nativas e pomares domésticos de dois municípios do Estado do Tocantins, Brasil. Revista Brasileira de Entomologia, vol. 51, no. 2, p. 217-223.

CANAL, NA, and ZUCCHI, RA., 2000. Parasitoides Braconidae. In MALAVASI, A. and ZUCCHI, RA. (Eds.). Moscas-das-frutas de importância econômica no Brasil: conhecimento básico e aplicado. São Paulo: Holos. p. 119-126.

CARABALLO, J., 2001. Diagnosis y clave pictórica para las especies del género Anastrepha Schiner, 1868 (Diptera: Tephritidae) de importancia económica en Venezuela. Entomotropica, vol. 16, no. 3, p. 157-164.

CELEDÔNIO-HURTADO, HM., ALUJA, M. and LIEDO, P., 1995. Adult population of Anastrepha species (Diptera: Tephritidae) in tropical orchard habitats of Chiapas, México. Environmental Entomology, vol. 24, no. 4, p. 861869. 
DAJOZ, R., 1983. Ecologia geral. São Paulo: Ed. Vozes. 472 p. DEUS, EG., SILVA, RA., JESUS, CR. and SOUZA-FILHO, MF., 2009a. Primeiro registro de Anastrepha shannoni Stone (Diptera: Tephritidae) no estado do Amapá. Arquivos do Instituto Biológico, vol. 76, no. 4, p. 725-728.

DEUS, EG., SILVA, RA., NASCIMENTO, DB., MARINHO, CF. and ZUCCHI, RA., 2009b. Hospedeiros e parasitoides de espécies de Anastrepha (Diptera, Tephritidae) em dois municípios do Estado do Amapá. Revista de Agricultura, vol. 84, no. 3, p. 194-203.

DUTRA, VS., SANTOS, MS., SOUZA-FILHO, ZA., ARAUJO, EL. and SILVA, JG., 2009. Faunistic analysis of Anastrepha spp. (Diptera: Tephritidae) on a Guava Orchard under organic management in the Municipality of Una, Bahia, Brazil. Neotropical Entomology, vol. 38, no. 1, p. 133-138.

DUYCK, PF., DAVID, P., JUNOD, G., BRUNEL, C., DUPONT, R. and QUILICI, S., 2006. Importance of competition mechanisms in successive invasions by polyphagous tephritids in La Réunion. Ecology, vol. 87, no. 7, p. 1170-1180.

DUYCK, PF., DAVID, P. and QUILICI, S., 2004. A review of relationships between interspecific (Diptera: Tephritidae). Ecological Entomology, vol. 29, no. 5, p. 511-520.

GOULD, WP. and RAGA, A., 2002. Pests of guava. In PEÑA, JE, SHARP, JL and WYSOKI, M. (Eds). Tropical Fruit Pests and Pollinators: Biology, Economic Importance, Natural Enemies and Control. Wallingford: CAB. p. 295-313.

HEDSTRÖM, I., 1987. Fruit flies (Diptera: Tephritidae) infesting common guava (Psidium guajava L.) (Myrtaceae) in Ecuador. Revista de Biología Tropical, vol. 35, no. 1, p. 373-374.

JIRÓN, LF. and HEDSTRÖM, I., 1988. Occurrence of fruit flies of the genera Anastrepha and Ceratitis (Diptera: Tephritidae), and their host plant availability in Costa Rica. Florida Entomologist, vol. 71, no. 1, p. 62-73.

JIRÓN, LF., HEDSTRÖM, I. and NORRBOM, A., 1988. A preliminary list of the fruit flies of the genus Anastrepha (Diptera: Tephritidae) in Costa Rica. Florida Entomologist, vol. 71, no. 2, p. 130-137.

KATIYAR, KP., MOLINA, JC. and MATHEUS, R., 2000. Fruit flies (Diptera: Tephritidae) infesting fruits of the genus Psidium (Myrtaceae) and their altitudinal distribution in western Venezuela. Florida Entomologist, vol. 83, no. 4 p. $480-485$.

LEONEL JÚNIOR, FL., ZUCCHI, RA. and WHARTON, RA., 1995. Distribution and Tephritid hosts (Diptera) of braconid parasitoids (Hymenoptera) in Brazil. International Journal of Pest Management, vol. 41, no. 4, p. 208-213.

MALAVASI, A., 2000. Áreas livres ou de baixa prevalência. In MALAVASI, A. and ZUCCHI, RA. (Eds.). Moscas-dasfrutas de importância econômica no Brasil: conhecimento básico e aplicado. São Paulo: Holos. p.175-181.

MALAVASI, A., ZUCCHI, RA. and SUGAYAMA, RL., 2000. Biogeografia. In MALAVASI, A. and ZUCCHI, RA. (Eds.). Moscas-das-frutas de importância econômica no Brasil: conhecimento básico e aplicado. São Paulo: Holos. p.93-98.

MARSARO JÚNIOR, AL., RONCHI-TELES, B., BARBOSA, RI., SILVA-JÚNIOR, RJ., AGUIAR, RM. and SILVA, RA., 2011a. Conhecimento sobre moscas-das-frutas no estado de Roraima. In SILVA, RA., LEMOS, WP. and ZUCCHI, RA. (Eds.). Moscas-das-frutas na Amazônia brasileira: diversidade, hospedeiros e inimigos naturais. Macapá: Embrapa Amapá. p. 279-290.

MARSARO JÚNIOR, AL., ADAIME, R., RONCHI-TELES, B., LIMA, CR. and PEREIRA, PRVS., 2011b. Anastrepha species (Diptera: Tephritidae), their hosts and parasitoids in the extreme north of Brazil. Biota Neotropica, vol. 11, no. 4, p. 117-124.

MARSARO JÚNIOR, AL., NASCIMENTO, DB., RONCHITELES, B. and ADAIME, R., 2012. Faunistic analysis of Anastrepha Schiner (Diptera: Tephritidae) in three municipalities of the state of Roraima, Brazil. Brazilian Journal of Biology, vol. 72, no. 4, p. 813-819.

MARSARO JÚNIOR, AL., ADAIME, R., SOUZA-FILHO, MF., LIMA, CR. and TRASSATO, LC., 2013. Anastrepha fruit flies (Diptera, Tephritidae) from two municipalities of the state of Roraima, Brazil, with three new records. Revista de Agricultura, vol. 88, no. 1, p. 41-43.

MENZEL, CM., 1985. Guava: an exotic fruit with potencial in Queensland. Queensland Agricultural Journal, vol. 111, no. 2 p. 93-98.

MOURA, AP. and MOURA, DCM., 2006. Espécies de moscas-das-frutas (Diptera: Tephritidae) associadas à cultura da goiabeira (Psidium guajava L.) em Fortaleza, Ceará. Arquivos do Instituto Biológico, vol. 73, no. 1, p. 65-71.

NORRBOM, AL. and UCHÔA, MA., 2011. New species and records of Anastrepha (Diptera: Tephritidae) from Brazil, Zootaxa, vol. 2835, p. 61-67.

OVRUSKI, S., ALUJA, M., SIVINSKI, J. and WHARTON, R., 2000. Hymenopteran parasitoids on fruit-infesting Tephritidae (Diptera) in Latin America and the southern United States: Diversity, distribution, taxonomic status and their use in fruit fly biological control. Integrated Pest Management Reviews, vol. 5, no. 2, p. 81-107.

PEREIRA, JDB., BURITI, DP., LEMOS, WP., SILVA, WR. and SILVA, RA., 2010. Espécies de Anastrepha Schiner (Diptera: Tephritidae), seus hospedeiros e parasitoides nos estados do Acre e Rondônia, Brasil. Biota Neotropica, vol. 10 , no. 3 , p. 441-446.

RAFAEL, JA., 1991. Insetos coletados durante o Projeto Maracá, Roraima, Brasil: lista complementar. Acta Amazonica, vol. 21, no. 4, p. 325-336.

RAGA, A., MACHADO, RA., SOUZA-FILHO, MF., SATO, ME. and SILOTO, RC., 2005. Tephritoidea (Diptera) species from Myrtaceae fruits in the State of São Paulo, Brazil. Entomotropica, vol. 20, no. 1, p. 11-14.

RAMOS, DP., SILVA, AC., LEONEL, S., COSTA, SM. and DAMATTO-JÚNIOR, EV., 2010. Produção e qualidade de frutos da goiabeira 'Paluma', submetida à diferentes épocas de poda em clima subtropical. Revista Ceres, vol. 57 , no. 5 , p. 659-664.

RONCHI-TELES, B. and SILVA, NM., 2005. Flutuação populacional de espécies de Anastrepha Schiner (Diptera: Tephritidae) na região de Manaus, AM. Neotropical Entomology, vol. 34, no. 5, p. 733-741.

SAKAGAMI, SF. and LAROCA, S., 1971. Relative abundance, phenology and flower visited of apid bees in eastern Paraná, Southern Brazil (Hymenoptera: Apidae). Kontŷu, vol. 39, no. 3, p. 217-230.

SANTOS, MS., NAVACK, KI., ARAUJO, EL. and SILVA, JG., 2011. Análise faunística e flutuação populacional de moscas-das-frutas (Diptera: Tephritidae) em Belmonte, Bahia. Revista Caatinga, vol. 24, no. 4, p. 86-93.

SILVA, NM. and RONCHI-TELES, B., 2000. Amapá, Amazonas, Pará, Rondônia e Roraima. In MALAVASI, A. and ZUCCHI, RA. (Eds.). Moscas-das-frutas de importância 
econômica no Brasil: conhecimento básico e aplicado. São Paulo: Holos. p.203-209.

SILVA, RA., XAVIER, SLO., SOUZA-FILHO, MF., SILVA, WR., NASCIMENTO, DB., and DEUS, EG., 2007a. Frutíferas hospedeiras e parasitóides (Hym., Braconidae) de Anastrepha spp. (Dip., Tephritidae) na Ilha de Santana, Estado do Amapá, Brasil. Arquivos do Instituto Biológico, vol. 74, no. 2, p. 153-156.

SILVA, RA., NASCIMENTO, DB., DEUS EG., SOUZA, GD. and OLIVEIRA, LSP., 2007b. Hospedeiros e parasitóides de Anastrepha spp. (Diptera: Tephritidae) em Itaubal do Piririm, Estado do Amapá. Ciência Rural, vol. 37, no. 2, p. $557-560$.

SILVA, RA., DEUS, EG., PEREIRA, JDB., JESUS, CR., SOUZA-FILHO, MF. and ZUCCHI, RA., 2011a. Conhecimento sobre moscas-das-frutas no Estado do Amapá. In SILVA, RA., LEMOS, WP. and ZUCCHI, RA. (Eds.). Moscas-das-frutas na Amazônia brasileira: diversidade, hospedeiros e inimigos naturais. Macapá: Embrapa Amapá. p.223-236.

SILVA, RA., LEMOS, WP. and ZUCCHI, RA., 2011b. Ocorrência e hospedeiros de Ceratitis capitata na Amazônia brasileira. In SILVA, RA., LEMOS, WP. and ZUCCHI, RA. (Eds.). Moscas-das-frutas na Amazônia brasileira: diversidade, hospedeiros e inimigos naturais. Macapá: Embrapa Amapá. p.197-204.

SILVA, RA., LEMOS, WP. and ZUCCHI, RA., 2011c. Moscas-das-frutas na Amazônia brasileira: diversidade, hospedeiros e inimigos naturais. Macapá: Embrapa Amapá. $299 \mathrm{p}$.

SILVEIRA-NETO, S., NAKANO, O., BARBIN, D. and VILLA-NOVA, NA., 1976. Manual de ecologia dos insetos. São Paulo: Ceres. 419 p.

SOUZA-FILHO, MF., RAGA, A., AZEVEDO-FILHO, JA., STRIKIS, PC., GUIMARÃES, JA. and ZUCCHI, RA., 2009. Diversity and seasonality of fruit flies (Diptera: Tephritidae and Lonchaeidae) and their parasitoids (Hymenoptera: Braconidae and Figitidae) in orchards of guava, loquat and peach. Brazilian Journal of Biology, vol. 69 , no. 1 , p. $31-40$
THOMAZINI, MJ., ALBUQUERQUE, ES. and SOUZA-FILHO, MF., 2003. Primeiro registro de espécies de Anastrepha (Diptera: Tephritidae) no Estado do Acre. Neotropical Entomology, vol. 32, no. 4, p. 723-724.

UCHÔA, MA. and NICÁCIO, JN., 2010. New records of Neotropical fruit flies (Tephritidae), lance flies (Lonchaeidae) (Diptera: Tephritoidea), and their host plants in the South Pantanal and adjacent areas, Brazil. Annals of the Entomological Society of America, vol. 103, no. 5, p. 723-733.

UCHÔA, MA., OLIVEIRA, I., MOLINA, RMS. and ZUCCHI, RA., 2002. Species diversity of frugivorous flies (Diptera: Tephritidae) from host in the cerrado of the State of Mato Grosso do Sul, Brazil. Neotropical Entomology, vol. 31, no. 4 , p. 512-524.

URAMOTO, K., MARTINS, DS. and ZUCCHI, RA., 2008. Fruit flies (Diptera, Tephritidae) and their associations with native host plants in a remnant area of the highly endangered Atlantic Rain Forest in the State of Espírito Santo, Brazil. Bulletin of Entomological Research, vol. 98 , no. 5 , p. $457-466$

ZUCCHI, RA., 2000. Taxonomia. In MALAVASI, A. and ZUCCHI, RA. (Eds.). Moscas-das-frutas de importância econômica no Brasil: conhecimento básico e aplicado. São Paulo: Holos. p.13-24.

ZUCCHI, RA., 2001. Mosca-do-mediterrâneo, Ceratitis capitata (Diptera: Tephritidae). In VILELA, EF., ZUCCHI, RA. and CANTOR, F. (Eds.). Histórico e impacto das pragas introduzidas no Brasil. Ribeirão Preto: Holos. p.15-22.

ZUCCHI, RA., 2008. Fruit flies in Brazil - Anastrepha species and their hosts plants. Available from: www.lea.esalq.usp.br/anastrepha. Accessed in: $03 \mathrm{Fev}$. 2014.

ZUCCHI, RA., DEUS, EG. and SILVA, RA., 2011. Espécies de Anastrepha e seus hospedeiros na Amazônia brasileira. In SILVA, RA., LEMOS, WP. and ZUCCHI, RA. (Eds.). Moscas-das-frutas na Amazônia brasileira: diversidade, hospedeiros e inimigos naturais. Macapá: Embrapa Amapá. p. 51-70. 